\title{
The Politics and Ethics of Land Concessions in Rural Cambodia
}

\author{
Andreas Neef $\cdot$ Siphat Touch $\cdot$ Jamaree Chiengthong
}

Accepted: 6 February 2013/Published online: 14 March 2013

(C) The Author(s) 2013. This article is published with open access at Springerlink.com

\begin{abstract}
In rural Cambodia the rampant allocation of state land to political elites and foreign investors in the form of "Economic Land Concessions (ELCs)" estimated to cover an area equivalent to more than $50 \%$ of the country's arable land-has been associated with encroachment on farmland, community forests and indigenous territories and has contributed to a rapid increase of rural landlessness. By contrast, less than 7,000 ha of land have been allotted to land-poor and landless farmers under the pilot project for "Social Land Concessions (SLCs)" supported by various donor agencies. Drawing on fieldwork conducted in two research sites in Kratie Province, this article sheds light on the mechanisms and discourses surrounding the allocation of ELCs and SLCs. Our findings suggest that large-scale and non-transparent land leases in the form of ELCs are discursively justified as land policy measures supporting national development, creating employment opportunities in rural areas, and restoring "degraded" and "non-use" land, while SLCs are presented by the government and its international donors as a complementary policy to reduce landlessness, alleviate rural poverty, and ensure a more equitable land distribution. We argue that the SLC pilot project is a deliberate strategy deployed by the Cambodian ruling elite to instrumentalize international aid agencies in formalizing displacement and distributional injustices, in smoothing the adverse social
\end{abstract}

\footnotetext{
A. Neef $(\bowtie)$

Chair of Resource Governance and Participatory Development, Graduate School of Global Environmental Studies, Kyoto University, Yoshida-Honmachi, Sakyo-ku, Kyoto 606-8501, Japan e-mail: neef.andreas.4n@kyoto-u.ac.jp

S. Touch

Department of Research and Training, Ministry of Rural Development, Phnom Penh, Cambodia e-mail: touch.siphat@gmail.com

J. Chiengthong

Department of Sociology and Anthropology, Faculty of Social Science,

Chiang Mai University, Chiang Mai 50200, Thailand

e-mail: jamaree.c@cmu.ac.th
} 
impacts of their very own land policies and in minimizing resistance by dispossessed rural people.

Keywords Land grabbing - Land reform - Rural poverty ·

Political ecology $\cdot$ Discursive strategies

\section{Introduction}

Cambodia is endowed with relatively abundant natural resources. Arable land per capita is among the highest in Asia (World Bank 2010). Yet the distribution of these resources has become increasingly unequal in recent years. The United Nations Capital Development Fund estimated that in 2010 as much as $30 \%$ of Cambodia's land was owned by only $1 \%$ of the population (UNCDF 2010). The Royal Government of Cambodia (RGC) holds about 75-80 \% of the country's territory under the status of "state land" (USAID 2011). The 2001 Land Law allows the RGC to transfer "state public land" into "state private land" as a precondition to allocate concessions for various purposes. An increasing share of "state private land" has been allocated as Economic Land Concessions (ELCs) to Cambodian business tycoons, political elites and foreign investors since the mid-2000s, mostly for agro-industrial plantations. Some of these ELCs exceed by far the 10,000 ha that are set as the legal limit under the Cambodian Land Law of 2001 (OHCHRC 2007). This contrasts sharply with the total of less than 7,000 ha of land that was allotted by December 2011 to land-poor and landless farmers in the pilot sites for Social Land Concessions (SLCs) supported by various donor agencies under the Land Allocation for Social and Economic Development (LASED) program.

Land disputes and landlessness have sharply risen since the mid-2000s (NGOF 2011). By 2007, indigenous minorities had lost $30 \%$ of their traditional forest lands and poverty had risen from 40 to $58 \%$ percent in the mountainous/plateau provinces of northeastern Cambodia (MoP and UNDP 2007).

Drawing on fieldwork in northeastern Kratie Province, this study looks into the controversies and contradictions surrounding the allocation of Economic and Social Land Concessions in rural Cambodia. Specifically, we address the following research questions:

- What are the mechanisms of allocating ELCs and SLCs, and what are their impacts on rural people's livelihoods?

- What are the narratives and discursive tactics of the various actors involved in land distribution, land use planning and resource grabbing?

The remainder of this paper is organized as follows: in the next section we look at how economic and social land concessions have been embedded in the Land Law of 2001 and the Cambodian government's controversial land reform agenda. We then present two case studies from Kratie Province, one of the few rural provinces where both ELCs and SLCs have been granted in recent years. We synthesize and discuss our findings by deconstructing the narratives and discourses deployed by 
institutional actors towards legitimizing controversial land distribution programs and draw conclusions.

\section{Economic and Social Land Concessions in the 2001 Land Law and the Cambodian Land Reform}

Economic Land Concessions (ELCs) and Social Land Concessions (SLCs) are important pillars in the 2001 Land Law enacted after continuous pressure from international development banks to modernize Cambodia's legal system. Under this law it is possible for individuals, groups and corporations to apply for occupation and use of state land as a concessionaire (EWMI 2003). Concessions can be awarded in three forms: economic (for agro-industrial use), social (for residential and subsistence use) and others (such as mining or industrial developments). ELCs and SLCs have in common that they can only be granted after state public land has been converted into state private land.

\section{Economic Land Concessions in Cambodia: From Allocative Efficiency to Land} Grabbing

The history of granting ELCs in Cambodia dates back to French colonial times when large-scale rubber plantations were allocated to concessionaires (Slocomb 2007). After a disruption of the practice during the war-torn period from the 1950s to the late 1980s, land concessions experienced a renaissance in the early 1990s, when post-conflict Cambodia was rapidly transformed from a centrally planned into a market economy. After the first general elections in 1993, the RGC created more than 30 forestry concession zones covering about 6.5 million hectares and privatized those zones for exploitation (McKenney et al. 2004). Private forest concessions were cancelled in 2002, 1 year after the enactment of the Land Law of 2001, and reverted back into state property under the newly introduced legal category "state public land."

Following a short period of enhanced forest control under the Forest Administration, a new boom of land concessions started with the enactment of Sub-Decree 146 on Economic Land Concessions (RGC 2005) and a strong emphasis of the RGC on the promotion of agro-industrial plantations. The Cambodian League for the Promotion and Defense of Human Rights (LICADHO)—based on official government documents - maintains that as of February 2012 more than 2 million ha of land, an area equivalent to about $53 \%$ of Cambodia's arable land, have been carved out for 227 ELCs (Vrieze and Naren 2012). Many ELCs have been granted on indigenous land, although "indigenous community property" was introduced as a new legal category under the 2001 Land Law. Deiniger and Byerlee (2011: 146) hold that "[p]ublic information on economic land concessions remains incomplete, and many environmental and social impact assessments, if conducted at all, involve little community participation or fall short of international best practice."

In response to growing international and domestic criticism of the practice of granting ELCs, the Cambodian government adopted a new land policy rhetoric in 
the Land Policy Declaration of 2009 signed by the Prime Minister which states that "[1] and distribution shall ensure equity, social stability, food security and facilitate investment based on the natural characteristic, type and quality of soil for sustainable socio-economic development, prevent land concentration and promote productive and effective use of land" (Bickel and Löhr 2011: 33). In May 2012, the Prime Minister announced a moratorium on new economic land concessions and initiated a new land demarcation and titling program for poor rural communities, implemented with the help of youth volunteers. According to the latest report of the UN Special Rapporteur on the situation of human rights in Cambodia, this initiative lacks "comprehensive planning and harmonization with the existing legal framework and land titling system" (OHCHRC 2012: 37).

\section{Social Land Concessions: A Multi-Functional Instrument}

SLCs are a legal mechanism established under the Land Law of 2001 to allocate state private land to land-poor and landless households or community groups for social purposes, in particular for residential and agricultural use (EWMI 2001). According to the sub-decree 19 on "Social Land Concessions" an SLC may be granted in a variety of situations, such as resettlement, allotment of de-mined land and provision of subsistence plots for plantation workers, families of disabled soldiers or victims of natural disasters (RGC 2003). According to Article 49 of the land law, SLCs "allow the beneficiaries to build residential constructions and/or to cultivate lands belonging to the State for their subsistence" (EWMI 2003: 126).

The major pilot project for distribution of SLC land is the Land Allocation for Social and Economic Development (LASED) program, instigated in July 2008 under technical, administrative and financial support from the World Bank and German Development Assistance. The duration of the project is for 5 years with overall project costs of US\$ 11.5 million (NCDDS 2011). The plan is to provide 10,000 ha of land to a total of 3,000 households, i.e. so-called "Target Land Recipients (TLRs)." The initial target of the project was to allocate SLC land in 20 communes, but this number has been reduced to seven, because "the existing sites were much bigger than originally expected in terms of area covered as well as the number of land recipients" (2011: 4). As of September 2011, only 1,614 TLCs have received land under the LASED program and have been resettled to a total of 6,850 ha in the three provinces (NCDDS 2011).

The World Bank as the main donor and the National Committee for Democratic Development (NCDD) as the Cambodian implementing agency present individual success stories-featuring female-headed households-in their websites. Yet the process of SLC allocation has been slow and marred with persistent administrative hurdles and resource conflicts in the three LASED pilot provinces. In a preliminary assessment of the LASED project, Thiel (2010: 236) concluded that SLCs "lack effective implementation and show insignificant results." As a consequence, the German development cooperation in the distribution of SLC land was recently discontinued, while maintaining its support of former SLC recipients until 2013. Some NGOs maintain that SLCs were established as a tool to remove local people 
Table 1 Area of economic and social land concessions and its recipients (as of Dec. 2010)

\begin{tabular}{lll}
\hline Type of concession & Economic land concessions & Social land concessions \\
\hline Recipients & 49 companies & 885 households \\
Area (in ha) & $244,844.3$ & 3,906 \\
\hline
\end{tabular}

Source: KPDAFF 2010; RGC-LASED 2011

from their existing land rather than to provide land for them, citing examples from urban areas (e.g., LICADHO 2009).

\section{Economic and Social Land Concessions in Kratie Province: Two Case Studies}

\section{Study Region and Research Methodology}

Kratie Province is located in Northeastern Cambodia and covers an area of 11,094 km² with a total population of 319,124, of which 25,604 belong to indigenous groups according to the national census of 2008 (Schliesinger 2011). According to a report of the Kratie Provincial Department of Agriculture, Forestry and Fisheries (KPDAFF), 30 large-scale and 19 small-scale ${ }^{1}$ Economic Land Concessions (ELCs) were registered in the province as of 30 December 2010, covering a total area of 244,844.3 hectares (Table 1) or $22 \%$ of the province's territory (KPDAFF 2010). The majority of the large-scale ELCs have been leased by foreign investors (primarily Vietnamese and Chinese) for a period of 70 years, while most small-scale ELCs have been allocated to Cambodian businessmen. Figure 1 depicts the coverage of ELCs and SLCs and the location of the study villages.

In both case studies we used a mixed-method approach. The first case study combined various qualitative methods-key informant interviews, group discussions and participant observation-with a randomized survey of 30 households conducted with a structured questionnaire. In the second case study we used a combination of qualitative and participatory methods, namely key informant interviews, diagrams and mapping, group discussions, direct observation and conversational interviews. Table 2 provides an overview of the various field research phases.

Due to the sensitivity of the issues surrounding the controversy of Economic and Social Land Concessions in Cambodia, most of our informants requested strict anonymity. Some verbal information and classified documents were provided under condition of confidentiality only and thus could not be used in our description of case study results. However, this confidential information and material helped us to contextualize and interpret our findings.

Theoretical and Analytical Framework

Our study borrows and combines concepts and elements from the fields of political ecology and critical development studies. Political ecology approaches help exploring

\footnotetext{
1 Until September 2008, provincial governors could authorize the establishment of Economic Land Concessions not exceeding 1,000 ha. This practice was officially abolished by the Sub-Decree on the Modification of the Sub-Decree on Economic Land Concessions (RGC 2008).
} 
Table 2 Field research phases in Kratie province (2007-2012)

\begin{tabular}{lll}
\hline $\begin{array}{l}\text { Field research } \\
\text { phases }\end{array}$ & Case study I & Case study II \\
\hline Exploratory phase & May 2007 & June 2008 \\
$\begin{array}{l}\text { Main field } \\
\text { research }\end{array}$ & $\begin{array}{l}\text { November-December } \\
\text { Follow-up inquiry }\end{array}$ & $\begin{array}{c}\text { September-October } \\
2008\end{array}$ \\
\hline
\end{tabular}

how governments and their line agencies—often in conjunction with external advisors and producers of 'expert' knowledge-employ a variety of strategies to "governmentalize nature" (Whitehead et al. 2006: 52) and territorialize peripheral and marginal areas (e.g., Peluso and Vandergeest 2011), thereby enhancing control over both natural resources and rural/indigenous people. Delineation of national parks, reserved forest areas, and military-based protected areas are a way of legitimizing the exercise of exclusive managerial power of national governments over natural resources. Claiming and classifying forestland and forest resources as "state property" has been a common strategy of ordering and appropriating nature in most Southeast Asian countries (e.g., Peluso 1992; Forsyth and Walker 2008). In his seminal work "Seeing like a State," Scott (1998) identifies the administrative and simplified ordering of nature and society by the state as one major reason for failed planning that ignores local realities and knowledge systems. Beyond simplification and territorialization, Robbins (2007) describes other strategies deployed by "the state", including "building extractive ecologies" and "producing environmental narratives." The second strand of literature comes from the radical critique of mainstream "participatory' development in critical development studies (e.g., Cooke and Kothari 2001; Hickey and Mohan 2004). Scholars in this field argue that development practitioners have been overly naïve in their assumptions about power relations and how they are played out in rural development processes.

Much of the scholarship in these two disciplinary fields rejects apolitical perspectives on natural resource management and land reform processes and subscribes to normative presuppositions of environmental and distributional justice, fair access to natural resources and deliberative modes of decision-making (e.g., Robbins 2012). Our own normative stance in this study is that customary and indigenous rights to land and other resources they depend on for their livelihoods are as valid as modern land law promulgated by the state and that an elected government of a post-conflict nation like Cambodia has the moral obligation to correct distributional inequities resulting from the involuntary displacement and nullification of land rights during times of genocidal communist rule and armed conflict. We also presuppose that governments of countries with high incidence of rural poverty and livelihood dependency on natural resources ought to respect people's rights to subsistence and forest-based safety nets under the emerging concept of food sovereignty (cf. de Schutter 2011). Finally, we argue that international donor agencies should use their full leverage to ensure that guiding principles for responsible large-scale investments in land, such as participation, accountability and transparency, recognition of existing rights, compensation and 


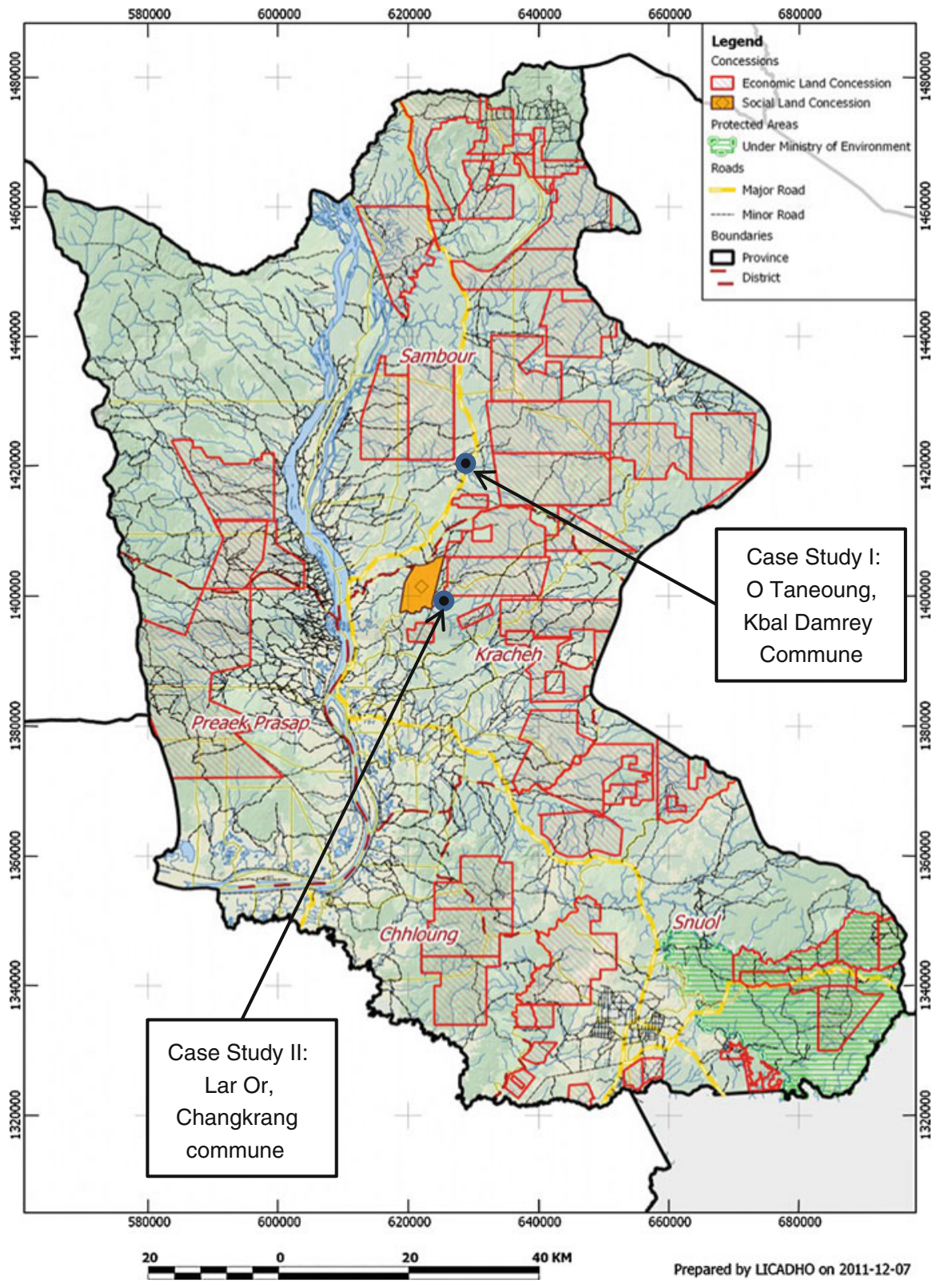

Fig. 1 Location of Economic and Social Land Concessions and study villages in Kratie Province Source: Map provided by Mathieu Pellerin (LICADHO)

fair sharing in the benefits of the investment, ecological and social sustainability, and the human right to food, are respected by host governments (cf. BMZ 2009; FAO 2012). 
Our analysis draws in part on the concept of discursive tactics, understood in this study as the things said and written that serve to both justify and simplify certain socio-political processes in rural development and to maintain established hierarchies and power relations in the local arena and beyond. In following Klak and Myers (1997), we discern three key discursive elements, namely depiction, fiction and omission. By "depiction" we refer to those issues that are part of the reality and emphasized by actors in their talks and written documents. By "omission" we make reference to the aspects of reality that are deliberately, i.e., strategically, left out from spoken and written accounts. "Fiction" refers to those messages and narratives that can be interpreted as "serious distortions of the local political-economic or societal context" (Klak and Myers 1997: 137).

\section{Case Study I: Economic Land Concessions in Kbal Dam Rey Commune}

Kbal Dam Rey Commune covers an area of $407 \mathrm{~km}^{2}$ and has had permanent settlements since the 1940s. The commune comprises five villages, of which $\mathrm{O}$ Tanoeung village was selected for this case study as it was directly affected by an Economic Land Concession in 2006. Local people do not have any formal land certificates, since Kratie Province is one of the eight provinces in Cambodia where no systematic land registration has been carried out to date (MLMUPC 2011). The livelihood of the villagers is primarily based on wet-rice cultivation, fishing, raising cattle, collection of non-timber forest products and seasonal off-farm work. The surrounding forests have always been an essential feature in the patterns of life of the villagers and continue to be of fundamental economic, cultural and social importance. Villagers who face land and food shortages and have few alternative livelihood opportunities can collect a range of forest resources for their household's subsistence. The community has been engaged in community forest initiatives since the mid-2000s. In February 2006, the Natural Resource and Environment Management project of the Seila ${ }^{2}$ program provided financial support to the commune to implement a community forestry project covering 1,468 ha, only three months before three foreign land concession projects were implemented and claimed a substantial part of the commune's land.

\section{Mechanism of the Large-Scale Land Lease and Impact on Villagers' Livelihoods}

In March 2006, three foreign companies-Green Island Agricultural Development; Global Agricultural Development; Asia World Agricultural Development-were granted a total amount of nearly 30,000 hectares of forestland. The three companies are owned by members of a Hong Kong-based Chinese family and use a joint office address in Phnom Penh (Gordon Claridge, pers. comm.). This is a common strategy employed to bypass the ceiling of 10,000 ha for ELC leases (cf. Vrieze and Naren 2012). Economic Land Concessions (ELCs) exceeding 1,000 ha need to be authorized by the national government, and investors need to approach the Cabinet

\footnotetext{
${ }^{2}$ The Seila program was the Cambodian government's program to mobilize aid and harmonize international funds for decentralization and deconcentration efforts.
} 
of the Prime Minister to request the permission for establishing a large ELC. In the case of the three companies that established ELCs in Kbal Dam Rey commune, the Prime Minister issued three letters, all dated on 22 December 2005, to order the Ministry of Agriculture, Forestry and Fisheries (MAFF) to conduct a study on the requested areas of 10,000 ha each. The Minister sent a "national study team" of five officials to Kratie Province to conduct a survey of the requested land areas. Following a meeting with the Kratie governor and representatives of other provincial departments on 9 January, a "provincial study team" was formed. The following day, the team split up into two groups that surveyed the forest situation, landscape characteristics, soil quality and local land use and completed their mission by 12 January. Approval signatures of all relevant local authorities, including the Sambo district governor and the commune leader of Kbal Damrey, were obtained by 13 January and the provincial governor sent the location maps for all three proposed areas with the signatures to the Minister of MAFF. The Minister of MAFF recommended to the Prime Minister in a letter dated 31 January that sufficient land was available for the three concessions. After having obtained the full delegation of power from the Prime Minister, the Minister of MAFF and the three recipient company owners signed the contracts on 15 March 2006, effectively according the latter a 70-year lease, i.e., a de facto unconditional land use right until the year 2076, after an approval process that took less than 3 months.

The three companies started to implement their concession projects in May 2006, with various impacts on the three communes Kbal Damrey, O Kreang and Rorlaus Meanchey. O Tanoeung villagers were directly affected by the Global Agricultural Development Company (GADC) which infringed on the western part of the village's territory. According to interviews in 30 households from $\mathrm{O}$ Tanoeung village, GADC had appeared in the community without any prior notice. Respondents unanimously stated that none of them had been consulted or informed about the planned concession beforehand. Only when the company started clearing the land, villagers became aware of the fact that the company was encroaching into the village territory.

The initial impact on villagers' livelihoods was substantial. Parts of the villagers' wet-rice fields were located in the concession area and were thus claimed by the company. Many cattle owners lost access to traditional pastures in secondary forest areas. At least six calves died in 2007 after falling into the trenches dug by the company in the process of demarcating the boundaries of the concession. The company also violated regulations in the 2001 Land Law that stipulates that roads or waterways used by local people cannot be blocked by a concession (cf. OHCHRC 2007). The concession also blocked the stream flow of local creeks that provided freshwater for household consumption, fishery activities and villagers' rice fields. Most importantly the concession infringed on the forest areas that were essential for local people's livelihoods. 855 ha of the planned community forest of 1,468 ha were located within the boundaries of the concession.

Krom Hun Chin (Chinese company) is clearing the forests. Forests no longer exist, and our lives will face difficulties in the near future. Our children will not see and know all trees and wild animals in this area. If the government sold 
land to the Chinese, what can we do? We are ignored and excluded(Mr. S., O

Tanoeung villager).

\section{Discursive Tactics and Contrasting Narratives}

In January 2007, the deputy provincial governor agreed to attend a meeting aimed at settling the dispute between the three companies and affected communities. The deputy governor was accompanied by company representatives, the district governor, other government officials (e.g., from the forestry office) and several armed police and military forces. In the meeting, villagers demanded that the companies withdraw from the three communities. The provincial deputy governor argued that the companies had received permissions by the national government to establish the three ELCs to develop tree plantations and wood processing factories. He claimed that the government granted only "state land" to the companies, not villagers' farmland. The deputy governor further suggested that those lands were "degraded" forest areas that were of "no use" for local people, therefore "the companies will help to develop local infrastructure and provide jobs to the local people in order to reduce poverty in the region." He emphasized that "in the future Cambodia will export wood products and get US-Dollars in return."

Yet the villagers maintained that most of the area was not "degraded" and "nonuse," but rather "old-growth and dense forest," locally known as prey chas, rich in biodiversity and valuable timber. This narrative was supported by the commune land use and natural resource map of 2006 that had been developed by the community forestry project under government and NGO support and had identified more than 50,000 ha of the commune territory as "dry evergreen broad-leafed forest, deciduous forest, and mixed forest."

O Tanoeung villagers also rejected the "poverty alleviation" and "job creation" narrative of the provincial deputy governor as fictitious:

Poverty in this community can be reduced, whenever the people have land for rice cultivation. In the future, the members of each family will increase and they will need land for rice production. But the companies now took over all reserve land, thus how can the new members acquire land, when they need it? [...] If they do not have land, how will poverty be reduced? (Ms C., villager).

In personal interviews during the household survey, villagers reiterated their strong determination that they would not work for the concessionaire, equating life as a plantation worker with "slavery."

The Chinese came to take over Khmer land and required Khmer people to work for them as slaves; even though we may die, we will not work for those land robbers. (Mr. S., villager).

Perhaps the government wants the people here to be slaves for foreigners on their own [Khmer] land rather than letting them work independently. (Mr. T., villager).

Villagers negotiated with the company to reclaim their wet-rice fields and to have the concession boundaries moved at least $500 \mathrm{~m}$ from their plots. Ultimately, the 
concessionaire offered to release all wet-rice fields, but insisted to move the ELC boundaries only $100 \mathrm{~m}$ from the farmers' fields. Local and international $\mathrm{NGOs}^{3}$ that wanted to help the affected villages in Kbal Damrey commune in their conflict with the three concessionaires faced severe restrictions and pressure from companies and provincial authorities in the second half of 2007. To quell any organized form of resistance, the provincial governor issued a letter in August 2007 that prohibited the operations of an NGO network in the province, on the grounds that it was not registered with the Ministry of Interior.

In 2010, the community forestry initiative was finally approved, but only on the area of 613 ha that was located outside the boundaries of GADC. As of February 2012 no activities were recorded in the concession, ${ }^{4}$ apart from small patches of land that were subcontracted to a few Khmer businessmen from Kratie town and Kampong Cham Province and a Khmer-Canadian investor for growing cassava. Meanwhile, the number of Economic Land Concessions in Kbal Damrey commune had increased to nine, of which seven are large-scale. An increasing number of villagers were involved in illegal logging as collection of non-timber forest products in the concession areas was no longer possible. In O Tanoeung village, members of at least 10 families had to work as seasonal laborers for farmers in other communities in order to sustain their livelihoods.

\section{Case Study II: Social Land Concessions in Sambok and Changkrang Communes}

The two communes Sambok and Changkrang in Chet Borey District, Kratie Province, have been the major targets of the pilot project of SLC allocation under the Land Allocation for Social and Economic Development (LASED). In the two communes, 3,906 ha of SLC land were allocated to 885 TLRs by October 2011 (RGC and LASED 2011). Since not all applications from eligible families could be accepted, a pre-selection needed to be done based on a commune-based poverty assessment, followed by a "lucky draw" that determined the location of the SLC land allocated to the beneficiaries.

\section{Processes of Allocating Social Land Concessions (SLCs) to the Rural Poor:} Competing Narratives and Discourses

According to the website of the National Committee for Democratic Development (NCDD) — the Cambodian government's implementing body-LASED is distributing "good quality state land" (NCDD 2011). One of the international project

\footnotetext{
3 At the time of the 2007 survey, 17 local NGOs and 3 international NGOs were operating in Kratie province.

4 This underscores the assumption that the principal reason for the acquisition of the concession was the valuable timber growing in the area, which is also supported by company documents (Gordon Claridge, pers. comm.).

5 From an ethical point of view it may be questionable whether decisions regarding rural people's longterm livelihoods should be left to a "lucky draw process." Yet the LASED project staff maintained that it was a fair procedure.
} 
advisors stated, however, that "soil fertility in the SLC project area is extremely low" (K.G., personal communication June 2008) since the area had been previously exploited by the Kingwood logging company that had extracted all valuable trees in the mid-1990s. In fact, according to an agro-ecosystem analysis conducted in 2006 by a team of international consultants and local government officials, around $70 \%$ of the SLC area was covered with poor sandy to silty Acrisols with very shallow soil depth and limited suitability for agriculture (KPDAFF 2006). Hence, the number of nearly 900 beneficiaries in the SLC area in Changkrang and Sambok communes may by far exceed the long-term carrying capacity of the land; the agro-ecosystem analysis of 2006 found the land suitable for a maximum number of 400 farm families, considering the low soil fertility and the need for ecological conservation and restoration of some parts. LASED staff and a Changkrang commune official confirmed that there is practically no reserve land available in the SLC area. A LASED technical advisor stated:

Providing land for the young generation is beyond the project. The current recipients will increase their 'economic level', then they can buy more land and send their children to high school or even universities. In the future, some recipients can also work in the factories, like in Malaysia.

The National Committee for Democratic Development (NCDD) maintains on its official website that SLC land is distributed through "transparent and technically appropriate mechanisms" (NCDD 2011). Yet LASED technical staff conceded in informal talks that "the poorest of the poor did not apply for SLC land" due to a number of reasons, such as health problems, illiteracy and "because they were afraid that they won't be able to comply with the regulations in the SLC certificates." In a focus group discussion in an indigenous Phnong sub-community of Kor Sang village, Changkrang commune, villagers claimed that some of the households that were assigned to the poorest category were actually among the wealthiest in the community. The focus group participants maintained that they were not informed about the decision-making process on approving SLC applications and that it was simply announced to them on an individual basis whose applications had been successful.

This statement is at odds with the findings of the 2011 mid-term review which holds that " $[t]$ he selection of beneficiaries seems to have been conducted in a transparent manner and they were sufficiently informed of the rights and possibilities associated with moving to sites. The mission did not find any evidence that the beneficiaries moved to sites under coercion or against their will" (RGC and LASED 2011: 9). While this may hold true for the beneficiaries, this narrative omits the fact that around 130 households who had settled in the Kratie project site after 2001 - but prior to the beginning of the land distribution process in 2009 - were moved out of the SLC area, as they were considered "illegal encroachers on state land."

\section{The Ambiguous Relationship Between Economic and Social Land Concessions}

Lar Or is a sub-community of Kor Sang village in Changkrang commune, located at the southeastern border of the LASED pilot site in Kratie Province. The majority of 
its inhabitants belong to the Phnong indigenous group, with a small Khmer minority. The community moved to its current location in 1997 after the Kingwood logging company had left the area. They had formerly used the area of what is now the SLC pilot site for grazing their animals and collecting firewood and non-timber forests. In contrast to their being depicted as 'primitive shifting cultivators' by the government, they also practice wet-rice cultivation, have a highly diversified homegarden system and maintain a rotational swidden farming system (known as chamkar) with fallow periods of up to 5 years. Many villagers had expected to receive SLC land from the LASED project.

In August 2008, while they still waited for the start of the SLC land allocation process, a Khmer concessionaire with a government-sanctioned ELC contract claimed 3,600 ha of land in the eastern part of the community's territory. The villagers only realized that the concession infringed on their land when company workers asked for their cooperation in demarcating the concession's boundaries.

The company claimed parts of our wet-rice fields, a great share of our chamkar land and our sacred cemetery forest. We asked for legal advice from a local NGO and we collected fingerprints from all villagers to send a petition to the provincial governor (Focus Group Discussion (FGD), February 2012).

After the legal consultations with the NGO in September 2008 - which we attended as observers - the villagers asked the company director for a meeting. Representatives of all 78 households were present at the village meeting and after a heated debate the director bowed to the pressure of the villagers and agreed to move the western boundary of the concession by 1,500 $\mathrm{m}$. The company grows Jatropha curcas and cassava for export to Vietnam. As of February 2012, none of the villagers worked for the company.

We need to take care of our own cassava fields. Why should we work on the cassava fields of the Khmer concessionaire? (FGD, February 2012).

In 2009 and 2010 a total of 39 households in the community received farmland in the LASED Social Land Concession area during the two rounds of land allocation. In 2010, the sub-village leader formed a community forestry group to protect 2,700 ha of forest around a cultural site comprising four ancient temples and two ancient ponds. Community members have put various poles around the site to protect it from encroachment. The initiative had been supported by the Kratie Provincial Departments of Environment and of Culture and Fine Arts, UNESCO. A document titled "Internal Regulations for the Community Committee for Natural and Cultural Resource Conservation" was signed by all relevant local authorities, including the provincial governor, in October 2010. The 13 members of the community forest group believed that this was the final legal document and were not aware that their community forestry initiative was not processed further to the Forest Administration whose signature would be a prerequisite for a legally binding community forest agreement according to the Forest Law of 2002.

In July 2011, a Vietnamese company started to demarcate another Economic Land Concession of 3,900 ha which includes the entire community forest and the cultural sites protected by the Phnong community. It also encroaches into 510 ha of 
villagers' rotational swidden land (chamkar). Again, villagers had neither been consulted nor informed of the government's decision to grant the ELC. Villagers stated in a group discussion:

We never met the owner and we do not know what the company wants to grow in the concession area. The company has already cleared $300 \times 1300 \mathrm{~m}$ of land and is currently making construction material from wood (FGD, February 2012).

A commune official reported that in addition to the two large-scale ELCs approved at the national level, there are another four small-scale concessions currently operating in Changkrang commune, all of which were granted by the provincial governor.

As a response, the Phnong village leader proposed to his fellow community members to establish their own 'community concession' area. Each family was asked to clear an area of 2 ha within the Vietnamese concession area to defend the village's land use rights.

We are not sure whether this strategy will work, but it is the only thing we can do at this moment. Our community has grown to more than 100 families; we need to protect our land. (FGD, February 2012).

\section{Creating Partnerships Between Economic Land Concessionaires and SLC Recipients: Opportunity or fiction?}

As a consequence of the slow pace of SLC land identification and allocation and the increasing competition between ELCs and SLCs, the German development contribution to the LASED project has recently switched from land distribution to consolidating the livelihoods of LASED land recipients. The major strategy towards the goal of "livelihood consolidation" is to create partnerships between Economic Land Concessions (ELCs) and Social Land Concessions (SLCs). A LASED advisor described these plans in the following words:

We plan to bring ELCs and SLC recipients together in a partnership approach. [...] We need to organize the labor force of the farmers to be able to work for the ELCs which will reduce their labor procurement costs. Farmers will learn new technologies and negotiation skills.

Various such public-private partnership (PPP) models have been proposed and discussed, such as contract farming or smallholder partnership farming, 'outgrower' schemes based on sub-lease contracts granted by the ELCs, and community titles for SLC recipients living at the edges of large-scale ELCs (e.g. Müller and Poch 2011; Bickel and Löhr 2011). In fact, such ELC-SLC partnerships were already emphasized in the evaluation criteria of ELCs in Article 5 of Sub-Decree 146 on Economic Land Concessions (RGC 2005). The government's policy rhetoric on ELC-SLC partnerships is echoed by provincial administrators and development experts alike, who also maintain that the success of such partnerships should 
emanate from the self-interest of investors and smallholders, as the following quotes show:

ELCs provide job opportunities for SLC recipients, the companies can buy farmers' crops and they will restore the forests. (Officer from the Provincial Department of Rural Development in Kratie, February 2012).

Since ELC-holders are often in need of skilled labour and smallholders in turn lack access to sufficient land resources, it is self-evident that such a partnership could be mutually beneficial (Bickel and Löhr 2011: 34).

Yet a former LASED consultant expressed deep skepticism regarding the possibility of engaging concessionaires in partnerships with SLC recipients:

I don't trust the Chinese and Vietnamese 'business partners.' They want to maximize profits. Period. (E-mail interview, February 2012).

In informal talks with LASED advisors we found that they were well aware of the fact that many ELC projects in Cambodia violate international donors' principles of fair and responsible investments in land. Yet they maintain that aid agencies should remain committed to their engagement in the land reform sector:

If we were not involved in the land policy sector, things would be even worse here. [...]. Without the money of the donors the LASED project would never have taken off. (LASED advisor, February 2012).

\section{Synthesis and Discussion}

Our first case study confirms earlier independent reports of the adverse effects of Economic Land Concessions on local people's livelihoods, community-based resource management initiatives and ecological integrity in the less populated provinces of the country. The indiscriminate allocation of ELCs has led to enclosures of communally managed land, dispossession of small peasants and overlapping claims over private leasehold, community forests, indigenous territories and state land. Since neither private agricultural land nor communal land has been officially titled in Kratie Province to date, all land resources are "state land" by default. Farmers and local communities are not considered as legal landholders, and government entities do not feel obliged to negotiate with local people prior to granting concessions.

Our second case study juxtaposes the rapid process of granting ELCs of several thousand hectares in a single deal with the slow process of allocating comparatively small pieces of land to the landless and land-poor. The initial aim of the international donors involved in the LASED project was apparently to strike a balance between the allocation of large ELCs to private investors and the provision of SLC land to the poor, but they proved to have little leverage on accelerating land grabbing and dispossession processes in their target areas. The findings of our case study in the LASED pilot project areas lend credence to the interpretation that Social Land Concessions are not intended primarily as a pro-poor development 
Table 3 Dominant narratives and discursive strategies employed by government officials and LASED project staff

\begin{tabular}{|c|c|c|c|}
\hline $\begin{array}{l}\text { Discursive } \\
\text { elements }\end{array}$ & $\begin{array}{l}\text { Economic land concessions } \\
\text { (ELCs) }\end{array}$ & $\begin{array}{l}\text { Social land concessions } \\
\text { (SLCs) }\end{array}$ & $\begin{array}{l}\text { Relationship between ELCS } \\
\text { and SLCs }\end{array}$ \\
\hline Depiction & $\begin{array}{l}\text { ELCs are a measure of } \\
\text { 'allocative efficiency', } \\
\text { ELCs help develop the } \\
\text { national economy, they } \\
\text { provide commodities for } \\
\text { export, and enhance } \\
\text { government revenues }\end{array}$ & $\begin{array}{l}\text { SLCs provide land for poor } \\
\text { families, resettlements to } \\
\text { SLC areas are voluntary, } \\
\text { SLC land provides secure } \\
\text { use rights and gives } \\
\text { special attention to women } \\
\text { and the disadvantaged }\end{array}$ & $\begin{array}{l}\text { ELCs and SLCs are } \\
\text { complementary measures } \\
\text { that can help to implement } \\
\text { the land reform and rural } \\
\text { development agenda of } \\
\text { the government }\end{array}$ \\
\hline Omission & $\begin{array}{l}\text { ELCs infringe on villagers' } \\
\text { farmland, communal } \\
\text { pastures, community } \\
\text { forests and public } \\
\text { infrastructure; ELC } \\
\text { approval processes lack } \\
\text { transparency and } \\
\text { accountability }\end{array}$ & $\begin{array}{l}\text { Landlessness may be a } \\
\text { result of previous } \\
\text { evictions from state land; } \\
\text { indigenous people could } \\
\text { claim their territory as } \\
\text { communal land rather than } \\
\text { applying for SLCs }\end{array}$ & $\begin{array}{l}\text { ELCs and SLCs may } \\
\text { compete for the same land } \\
\text { resources; SLCs may be } \\
\text { strategically located in } \\
\text { areas where villagers face } \\
\text { resettlement from their } \\
\text { customary land by ELCs }\end{array}$ \\
\hline Fiction & $\begin{array}{l}\text { ELCs help restore 'non-use' } \\
\text { land and 'degraded forest' } \\
\text { areas; ELCs create } \\
\text { employment opportunities } \\
\text { for local people and } \\
\text { diversify the local } \\
\text { economy and ecology }\end{array}$ & $\begin{array}{l}\text { SLCs are a measure of } \\
\text { 'distributive justice'; } \\
\text { SLCs provide good quality } \\
\text { agricultural land; SLCs } \\
\text { will lift farmers out of } \\
\text { poverty }\end{array}$ & $\begin{array}{l}\text { Partnerships and win-win } \\
\text { arrangements between } \\
\text { ELCs and SLCs are } \\
\text { possible under the current } \\
\text { institutional and political } \\
\text { environment }\end{array}$ \\
\hline
\end{tabular}

strategy by a benevolent and paternalistic Cambodian government, but rather as a means to provide reserve land for evicted and dispossessed peasants in order to sustain a form of "shadow governance" (Le Billon 2002: 573) by the political elite and to minimize resistance against land grabbing in the form of Economic Land Concessions.

The official narratives and discursive strategies of government officials and foreign development experts involved in land distribution are thus complementary and blend well to create an image of Economic Land Concessions and Social Land Concessions as complementary measures in promoting land reform and rural development in marginal areas (Table 3). While ELCs supposedly warrant "allocative efficiency," provide employment opportunities and open up export markets, SLCs are depicted as providing secure land rights for the poor, the women and other marginalized groups and thus promoting "distributive justice." What is omitted in this official development discourse is the extra-legal and non-transparent character of ELC deals and their infringement on communal indigenous lands, on small farmers' private fields and on community forests, that has met fierce resistance from Cambodian peasants. The rather fictitious "publicprivate partnership" rhetoric ignores the historical and contemporary factors underlying rural landlessness and to ex post legitimize and perpetuate the grave distributional

\footnotetext{
6 The concept of "shadow state" or "shadow governance" was coined by Reno (1995) who showed how politicians and warlords in Sierra Leone extended their personal rule and powers of patronage behind official policies by exploiting their relationships with international businesses.
} 
inequities associated with the implementation of the Cambodian government's land reform agenda.

Our findings suggest that the introduction of SLC schemes goes beyond mere "window dressing" (Thiel 2010: 236). Employing a three-fold strategy, the Cambodian ruling elite has in fact instrumentalized international aid agencies in their quest (1) to formalize dispossession, displacement and distributional inequities (2) to smooth the adverse social impacts of the RGC's very own land policies and (3) to minimize local opposition against evictions associated with the allocation of ELC land.

\section{Conclusion}

The on-going commodification of Cambodia's rich natural resources by the ruling elite and its widespread patronage network is intimately associated with the dispossession and disempowerment of rural people. Large-scale and widespread land grabbing in the form of Economic Land Concessions has been accompanied by an official discourse of national economic development, employment creation, reforestation, and poverty alleviation. In implementing its ambiguous land reform agenda, the Cambodian government with its various agencies has been trying to exert a more efficient and remunerative control of resources and people in areas that have until recently managed to escape from state power. Through apportioning and allocating huge tracts of formerly mosaic agricultural and forestland as concession land, the government has created new types of rural poverty and landlessness, while discursively justifying these measures as drivers of national economic development and ecological restoration. By perpetuating the myth of partnership, poverty reduction and participation through consensus-seeking discourses and non-controversial development narratives, international aid agencies involved in the land reform sector have unwillingly become accomplices of government elites that have proven increasingly unaccountable to the rural poor.

Acknowledgments We are grateful to Manfred Hornung for providing important background documents and to Christoph Oldenburg, Rupert Friederichsen, Gordon Claridge, Konrad Ott and Lieske Voget-Kleschin as well as four anonymous reviewers who gave valuable comments on earlier versions of this paper. We are indebted to Mathieu Pellerin (LICADHO) who provided the detailed map of Kratie Province. We would like to thank all those informants who shared their knowledge under conditions of anonymity.

Open Access This article is distributed under the terms of the Creative Commons Attribution License which permits any use, distribution, and reproduction in any medium, provided the original author(s) and the source are credited.

\section{References}

Bickel, M., \& Löhr, D. (2011). Pro-poor land distribution in Cambodia. Rural, 21(3), 33-35.

BMZ. (2009). Development policy stance on the topic of land grabbing-the purchase and leasing of large areas of land in developing countries. Bonn: BMZ-Federal Ministry for Economic Cooperation and Development. 
Cooke, B., \& Kothari, U. (2001). The case for participation as tyranny. In B. Cooke \& U. Kothari (Eds.), Participation: The new tyranny? (pp. 1-15). London: Zed Books.

De Schutter, O. (2011). How not to think of land-grabbing: Three critiques of large-scale investments in farmland. Journal of Peasant Studies, 38(2), 249-279.

Deininger, K., \& Byerlee, D. (2011). Rising global interest in farmland: Can it yield sustainable and equitable benefits?. Washington DC: World Bank.

EWMI. (2003). Land Law of Cambodia: a study and research manual. Phnom Penh: East-West Management Institute (EWMI).

FAO. (2012). Voluntary Guidelines on the responsible governance of tenure of land, fisheries and forests in the context of national food security. Rome: Food and Agricultural Organization of the United Nations (FAO).

Forsyth, T., \& Walker, A. (2008). Forest guardians, forest destroyers: The politics of environmental knowledge in northern Thailand. Chiang Mai: Silkworm Books.

Hickey, S., \& Mohan, G. (Eds.). (2004). Participation: From tyranny to transformation. London: Zed Books.

Klak, T., \& Myers, G. (1997). The discursive tactics of neoliberal development in small third world countries. Geoforum, 28(2), 133-149.

KPDAFF. (2006). Agro-ecosystems analysis of the Kratie Social Land Concession area. Kratie: Kratie Provincial Department of Agriculture.

KPDAFF. (2010). Report on monitoring and evaluation of Economic Land Concessions in Kratie province (in Khmer). Kratie: Kratie Provincial Department of Agriculture, Forestry and Fisheries (KPDAFF).

Le Billon, P. (2002). Logging in muddy waters: The politics of forest exploitation in Cambodia. Critical Asian Studies, 34(4), 563-586.

LICADHO. (2009). Land grabbing and poverty in Cambodia: The myth of development. Phnom Penh: Cambodian League for the Promotion and Defense of Human Rights (LICADHO).

McKenney, B., Chea, Y., Tola, P., \& Evans, T. (2004). Focusing on Cambodia's high value forests: Livelihoods and management. Phnom Penh: Cambodia Development Resource Institute and Wildlife Conservation Society.

MLMUPC (2011) Land is Life. Newsletter, November 2011, Issue 2. Phnom Penh: Ministry of Land Management, Urban Planning and Construction (MLMUPC).

MoP and UNDP. (2007). Expanding choices for rural people. Cambodia human development report 2007. Phnom Penh: Ministry of Planning and United Nations Development Program (UNDP).

Müller, F.-V., \& Poch, S. (2011). Land distribution in Cambodia-Experiences and new approaches for state land management. Presentation at the FIG working week 2011 (pp. 18-22). Marakech: Bridging the Gap between Cultures.

NCDDS. (2011). Report of land allocation for social and economic development project (LASED) from 2008 up to 2011. Phnom Penh: National Committee for Sub National Democratic Development (NCDDS).

NGOF. (2011). Statistical analysis on land disputes in Cambodia, 2010. Phnom Penh: The NGO Forum in Cambodia (NGOF).

OHCHRC. (2007). Economic land concessions in Cambodia: A human rights perspective. Phnom Penh: Office of the UN High Commissioner for Human Rights Cambodia (OHCHRC).

OHCHRC. (2012). Addendum to the report of the special rapporteur on the situation of human rights in cambodia. office of the un high commissioner for human rights cambodia (OHCHRC). http:// cambodia.ohchr.org/EN/PagesFiles/Reports/SR-SRSG-Reports.htm (last accessed 9 October 2012).

Peluso, N. L. (1992). Rich forests, poor people: Resources control and resistance in Java. Berkeley: University of California Press.

Peluso, N. L., \& Vandergeest, P. (2011). Political ecologies of war and forests: Counter-insurgencies and the making of national natures. Annals of the Association of American Geographers, 101(3), 587-608.

Reno, W. (1995). Corruption and state politics in Sierra Leone. Cambridge: Cambridge University Press.

RGC. (2003). Sub-decree on social land concession. Phnom Penh: Royal Government of Cambodia (RGC).

RGC. (2005). Sub-decree on economic land concessions. Phnom Penh: Royal Government of Cambodia (RGC).

RGC. (2008). Sub-decree on the modification of the sub-decree on economic land concessions. Phnom Penh: Royal Government of Cambodia (RGC). 
RGC and LASED. (2011). Aide Memoire: Mid-Term Review and Sixth Joint IDA-GIZ Implementation Support Mission, 3-21 October 2011. Phnom Penh: Royal Government of Cambodia (RGC) and Land Allocation for Social and Economic Development (LASED) Project.

Robbins, P. (2007). Political ecology and the state: A postcard to political geography from the field. In K. Cox, M. Low, \& J. Robinson (Eds.), The SAGE handbook of political geography (pp. 205-218). London: Sage.

Robbins, P. (2012). Political ecology: A critical introduction. Chichester: John Wiley and Sons.

Schliesinger, J. (2011). Volume 1: Introduction and overview. Bangkok: White Lotus: Ethnic groups of Cambodia.

Scott, J. C. (1998). Seeing like a state: How certain schemes to improve the human condition have failed. New Haven: Yale University Press.

Slocomb, M. (2007). Colons and coolies: The development of Cambodia's rubber plantations. Bangkok: White Lotus.

Thiel, F. (2010). Donor-driven land reform in Cambodia-Property rights, planning, and land value taxation. Erdkunde, 64(3), 227-239.

UNCDF. (2010). Local development outlook Cambodia: Trends, policies, governance. Phnom Penh: United Nations Capital Development Fund (UNCDF).

USAID. (2011). Cambodia-Property rights and resource governance. USAID Country Profile. Phnom Penh: USAID. http://usaidlandtenure.net/usaidltprproducts/country-profiles/cambodia/cambodia-countryprofile.pdf (last accessed 26 February 2012).

Vrieze, P. and Naren, K. (2012). Carving up Cambodia: One concession at a time. The Cambodia Daily Weekend, Issue 730, March 10-11, 4-11.

Whitehead, M., Jones, M., \& Jones, R. (2006). Spatializing the ecological leviathan: Territorial strategies and the production of regional natures. Geografiska Annaler, 88(B 1), 49-65.

World Bank. (2010). World Development Indicators 2010. Washington, DC: World Bank. 